\title{
Association of HCV genotype with viral load among Iranian blood donors: a penalized logistic regression
}

\author{
Fahimeh Ranjbar Kermani ${ }^{1}$, Sedigheh Amini Kafi-Abad*1, Kamran Mousavi Hosseini ${ }^{1}$, \\ Mahtab Maghsudlu ${ }^{1}$, Zohreh Sharifi ${ }^{1}$, Mohammad Ali Mansournia ${ }^{2}$

\section{Abstract}

Background: Hepatitis C virus (HCV) is a blood born virus and the leading cause of advanced hepatitis disease. HCV genotype 3a is predominant among Iranian blood donors. The aim of this study was to evaluate the relationship between HCV genotype and HCV viral load.

Methods: In this analytical cross-sectional study 106 anti-HCV positive and HCV RNA positive blood donors referred to Iranian blood centers across the county were entered. HCV viral loads were determined by an in-house one step Taq Man Real-Time RT-PCR assay. Penalized logistic regression was performed for data analysis. STATA software version 13 was used for statistical analysis.

Results: The mean age was $37.94 \pm 9.04$ years ranged from 19 to 58 years. Male gender included $104(98.1 \%)$ of subjects. 31,10 and 65 subjects were infected with genotypes $1 \mathrm{a}, 1 \mathrm{~b}$, and 3a, respectively. The mean viral load was $1.44 \times 106 \pm 4.5 \times 105 \mathrm{IU} / \mathrm{ml}$. HCV viral load was not significantly different among subjects infected with HCV genotypes $1,1.49 \times 106 \pm 4.57 \times 106 \mathrm{IU} / \mathrm{ml}$ compare to genotype $3,1.40 \times 106 \pm 5.584 .58 \times 106 \mathrm{IU} / \mathrm{ml}(\mathrm{p}=0.93)$.

Conclusion: Although not significant, the frequency of subjects with high viral load $(>800,000 \mathrm{IU} / \mathrm{ml})$ was higher in subjects infected with genotype 3 than those of genotype 1. No associations were found between demographic characteristics and HCV genotype. Although the study was unable to find any association between HCV genotype and HCV viral load/ HCV viral load group, it highlighted the role of high viral load in the high circulation of HCV genotype 3a among Iranian blood donors.

Keywords: Blood donors, Hepatitis C, Viral load, Genotype, sequencing, Iran

Conflicts of Interest: None declared

Funding: High Institute for Research and education in Transfusion Medicine, Research Center of Blood Transfusion, Tehran, Iran

\section{*This work has been published under CC BY-NC-SA 1.0 license.}

Copyright $\odot$ Iran University of Medical Sciences

Cite this article as: Ranjbar Kermani F, Amini Kafi-Abad S, Mousavi Hosseini K, Maghsudlu M, Sharifi Z, Mansournia MA. Association of HCV genotype with viral load among Iranian blood donors: a penalized logistic regression. Med J Islam Repub Iran. 2019 (24 Dec);33:149. https://doi.org/10.47176/mjiri.33.149

\section{Introduction}

Hepatitis $\mathrm{C}$ virus (HCV) is a major health problem worldwide. HCV is one of the leading causes of acute and chronic liver diseases, the severity of which can range from a mild illness to a lifelong disease. The majority of patients are asymptomatic and unaware of their infection

Corresponding author: Dr Sedigheh Amini Kafi-Abad,dr.amini@gmail.com

1. Blood Transfusion Research Center, High Institute for Research and Education in Transfusion Medicine, Tehran, Iran

2. Department of Epidemiology and Biostatistics, School of Public Health, Tehran University of Medical Sciences, Tehran, Iran
(1). HCV is a blood-borne virus, and exposure to blood is the most common mode of HCV transmission. Annually, 399,000 persons die of hepatitis $\mathrm{C}$ due to cirrhosis and hepatocellular carcinoma. It is estimated that 71 million people are living with chronic HCV infection worldwide.

\section{$\uparrow$ What is "already known" in this topic:}

$\mathrm{HCV}$ is classified into seven major genotypes. Some studies have shown that HCV viral load in patients infected with HCV genotype 2 or 3 is lower than those infected with $\mathrm{HCV}$ genotype 1. Other studies have reported an association between high viral load and genotype 3 . The association was not clarified among Iranian blood donors.

\section{$\rightarrow$ What this article adds:}

Although we were unable to find any association between $\mathrm{HCV}$ genotype and $\mathrm{HCV}$ viral load, we highlighted the role of high viral load in the high circulation of HCV genotype $3 \mathrm{a}$ among Iranian blood donors. 
The prevalence of chronic HCV varies in different regions, and according to the World Health Organization (WHO), Eastern Mediterranean (2.3\%) and European $(1.5 \%)$ countries are the most affected regions, and the prevalence of this infection ranges from $0.5 \%$ to $1 \%$ in other WHO regions $(2,3)$. In Iran, the overall rate of $\mathrm{HCV}$ viremia is $0.4 \%$ (4).

$\mathrm{HCV}$ is a small, enveloped, positive-stranded RNA virus. HCV genome encodes a polyprotein of approximately 3000 amino acids in length. This polyprotein is posttranslationally cleaved to structural and nonstructural proteins (5). Due to the high genetic heterogeneity of HCV genome and based on phylogenetic analysis, up to now, $\mathrm{HCV}$ is classified into seven major genotypes, which includes many subtypes. HCV genotypes/subtypes are regionally spread around the world $(6,7)$. HCV genotypes 1,2 , and 3 are globally common, but the other genotypes are region-specific. A very recent study showed that HCV genotype 3 (subtype $3 a$ ) is the most frequent one followed by genotype 1 ( $1 \mathrm{a}$ and $1 \mathrm{~b}$ ) and revealed changes in molecular epidemiology of $\mathrm{HCV}$ from the previously most common genotype 1 to the currently most frequent genotype 3 among Iranian blood donors (8).

With the improvement of molecular methods, HCV RNA quantification has become possible. Both HCV genotyping and viral load testing are important for the management of HCV infection (9). It is suggested that HCV genotype is related to viral load, and specific HCV genotype affects HCV RNA level. Controversy exists over the relationship between HCV genotype and HCV viral load. Studies have shown that HCV viral load is significantly higher in patients infected with genotype 1 than those infected with genotype 2 or 3 (10-15). However, some other studies failed to find any significant association in this regard $(16,17)$. On the other hand, based on a cut-off value of approximately $6 \mathrm{log} 10 \mathrm{IU} / \mathrm{ml}(800,000 \mathrm{IU} / \mathrm{ml}$ or $1000,000 \mathrm{IU} / \mathrm{ml}$ according to former studies), some studies have reported an association between high viral load and genotype 3 , though in some studies, this association was not significant (17-21).

Given the discrepancy regarding the link between HCV genotype and viral load and due to the predominance of HCV genotype 3 a among Iranian blood donors, we sought to evaluate the relationship between $\mathrm{HCV}$ genotype and HCV viral load.

\section{Methods}

\section{Study population}

This analytical cross-sectional study was performed on HCV RNA-positive blood donors referred to the Iranian blood transfusion centers over the country during 20152017 (22). The subjects were positive in anti-HCV confirmation tests and did not have positive results in screening tests of HBV, HIV, and in seven provinces of Iran performing human T-lymphotropic virus (HTLV) screening test, they also did not have positive results in HTLV testing. A total of $9 \mathrm{ml}$ of whole blood was collected from the subjects in vacutainer tubes, and the samples were immediately centrifuged at 3000 rounds per minute (RPM) for $10 \mathrm{~min}$ and stored at $-70^{\circ} \mathrm{C}$ until sent to the central laboratory. The serum of all the samples was separated in $1.5 \mathrm{ml}$ microtubes and stored at $-70^{\circ} \mathrm{C}$ until further processing. A partial sequence of non-structural $5 \mathrm{~b}$ (NS5b) region of HCV genome was already amplified and sequenced for determining HCV genotypes in all the samples in the previous study of the authors (8). All the blood donors whose $\mathrm{HCV}$ genotype was determined were included in this study.

Therefore, 106 subjects with identified HCV genotype were subjected to HCV RNA quantification.

\section{RNA extraction and viral load determination}

TriPure Isolation Reagent (Roche, Germany) was used for RNA extraction according to the instruction of manufacturer. Eluted HCV RNA in $20 \mu \mathrm{L}$ elusion buffer was used for $\mathrm{HCV}$ viral load testing, $\mathrm{HCV}$ viral loads were determined by an in-house one-step TaqMan Real-Time RT-PCR assay using LightCycler instrument (Roche, Germany) to amplify a segment of non-coding region (NCR) of HCV genome that is described elsewhere (23). Briefly, $2 \mu \mathrm{l}$ of each extracted RNA sample and $18 \mu \mathrm{l}$ of one-step TaqMan Real-Time RT-PCR Master Mix were mixed in individual capillaries. The following program of thermal cycling was performed: $50^{\circ} \mathrm{C}$ for $15 \mathrm{~min}, 94^{\circ} \mathrm{C}$ for $10 \mathrm{~min}$, followed by 45 cycles of $95^{\circ} \mathrm{C}$ for $5 \mathrm{~s}, 60$ cycles for $20 \mathrm{~s}$, and $72{ }^{\circ} \mathrm{C}$ for $10 \mathrm{~s}$ followed by a cycle of $40^{\circ} \mathrm{C}$ for $30 \mathrm{~s}$. Four HCV RNA quantification standards (QS) of the artus HCV LC RT-PCR reagent (Qiagen, Hamburg $\mathrm{GmbH}$, Germany) were used, and all standards were calibrated against the world health organization (WHO) international HCV RNA standard. The lower and upper detection limits of the in-house one-step TaqMan Real-Time RT-PCR assay were $8 \times 10^{1} \mathrm{IU} / \mathrm{L}$ and $8 \times 10^{4} \mathrm{IU} / \mathrm{L}$.

\section{Statistical analysis}

Descriptive data were expressed as mean \pm standard deviation (SD) or percentages (\%). HCV RNA levels were grouped based on the cut-off value of $800,000 \mathrm{IU} / \mathrm{ml}$ : $\leq$ $800,000 \mathrm{IU} / \mathrm{ml}$ indicated low viral load and $>800,000$ $\mathrm{IU} / \mathrm{ml}$ signified high viral load $(20,24,25)$. Based on $10-$ year intervals, the subjects were grouped as 19-28, 29-38, 39-48, and 49-58 years old.

T-test and analysis of variance (ANOVA) were applied for comparison of $\mathrm{HCV}$ viral load according to gender, age group, and genotype. Penalized logistic regression model via data augmentation using the prior $\log -\mathrm{F}(2,2)$ was performed to deal with sparse data bias for analyzing the association between HCV viral load groups and age groups, gender, and HCV genotype (26-28), and the results were summarized as odds ratio (OR) with $95 \%$ confidence interval (CI). Alpha level of 0.05 was considered as the significance level. Statistical analyses were performed using STATA software (STATA 13 Corp., College Station, Texas).

\section{Ethical Statement}

The Ethics Committee of High Institute for Research and Education in Transfusion Medicine, Tehran, Iran, approved the study (code No: IR.TMI.REC.1394.1800 


\section{Results}

During the study period, 106 subjects were included. Out of the 106 blood donors, $65(61.32 \% \pm 9.6 \%)$ were infected with genotype 3 (subtype $3 a$ ), and 41 (38.68) were infected with genotype 1, 31 with subtype 1a $(29.25 \% \pm 9.0)$ and 10 with subtype $1 \mathrm{~b}(9.43 \% \pm 6.05)$. The mean age of the subjects was $37.94 \pm 9.04$ years (age range: $19-58$ years), and the median was 37 years. Most donors were male (98.1\% of subjects), and 2 were female. The mean viral load was $1.44 \times 10^{6} \pm 4.5 \times 10^{5} \mathrm{IU} / \mathrm{ml}$ (range: from $2.28 \times 10^{3}$ to $3.42 \times 10^{7} \mathrm{IU} / \mathrm{ml}$ ). The majority of the subjects $(74.53 \%)$ fell in the low viral load group (Table 1$)$.

As shown in Table 2, no significant relationship was found between mean viral load in donors infected with $\mathrm{HCV}$ and age group, gender, genotypes, and subtypes $(\mathrm{p}=0.639,0.686,0.931$, and 0.640 , respectively).

The rates of different viral load groups based on age group, gender, and genotype and the relevant ORs with 95\% CIs for penalized logistic regression model predicting high viral load are shown in Table 3. No association was found between viral load groups and age (OR: $1.03 \pm 0.03,95 \%$ CI $0.98-1.08, \mathrm{p}=0.204)$. Among all the age groups, blood donors with high HCV viral loads had lower frequencies than those with low viral loads, this rate was the highest in the 48-59 age group, though the relationship was not significant. Two (100\%) female patients and the majority of the male subjects $(74.04 \%)$ had low viral loads, but the association was not significant (OR: $1.89 \pm 0.25,95 \%$ CI $0.1-19.38, p=0.59)$. Insignificantly, the frequency of patients with high viral loads $(>800,000$
Table 1. Demographic and laboratory characteristics of 106 Iranian blood donors

\begin{tabular}{|c|c|}
\hline Characteristics & Value \\
\hline${ }^{*}$ Age (years), Mean $\pm * *$ SD & $37.94 \pm 9.04$ \\
\hline \multicolumn{2}{|l|}{ Age group (years), $\mathrm{N}(\%)$} \\
\hline $19-28$ & $16(15.38)$ \\
\hline $29-38$ & $41(39.42)$ \\
\hline $39-48$ & $33(31.73)$ \\
\hline $49-58$ & $14(13.46)$ \\
\hline \multicolumn{2}{|l|}{ Gender, N (\%) } \\
\hline Female & $2(1.89)$ \\
\hline Male & $104(98.11)$ \\
\hline \multicolumn{2}{|l|}{ HCV genotype, N (\%) } \\
\hline $1(1 a+1 b)$ & $41(38.68)$ \\
\hline $3(3 a)$ & $65(61.32)$ \\
\hline \multicolumn{2}{|l|}{ HCV viral load $\log _{10,,}(\mathrm{IU} / \mathrm{ml})$} \\
\hline Low $(\leq 800,000 \mathrm{IU} / \mathrm{ml}), \mathrm{N}(\%)$ & $79(74.53)$ \\
\hline High $(>800,000 \mathrm{IU} / \mathrm{ml}), \mathrm{N}(\%)$ & $27(25.45)$ \\
\hline
\end{tabular}

$\mathrm{IU} / \mathrm{ml}$ ) in subjects infected with genotype 3 was higher than that of genotype $1(26.15 \%$ vs. $24.39 \%$; OR: $1.09 \pm 0.48,95 \%$ CI $0.46-2.57, \mathrm{p}=0.85$ ) (Table 3 ).

\section{Discussion}

The association between HCV genotype and HCV viral load has been widely studied, and the results are conflicting. A significant association was reported by some studies, while some others failed to find any significant relationships. In the present study, the real-time technique was used for the quantification of HCV RNA among welldefined HCV genotype blood donors. Although the mean viral load in donors infected with HCV genotype 1a was Table 2. Distribution of hepatitis C virus viral load according to age group, gender and HCV genotype

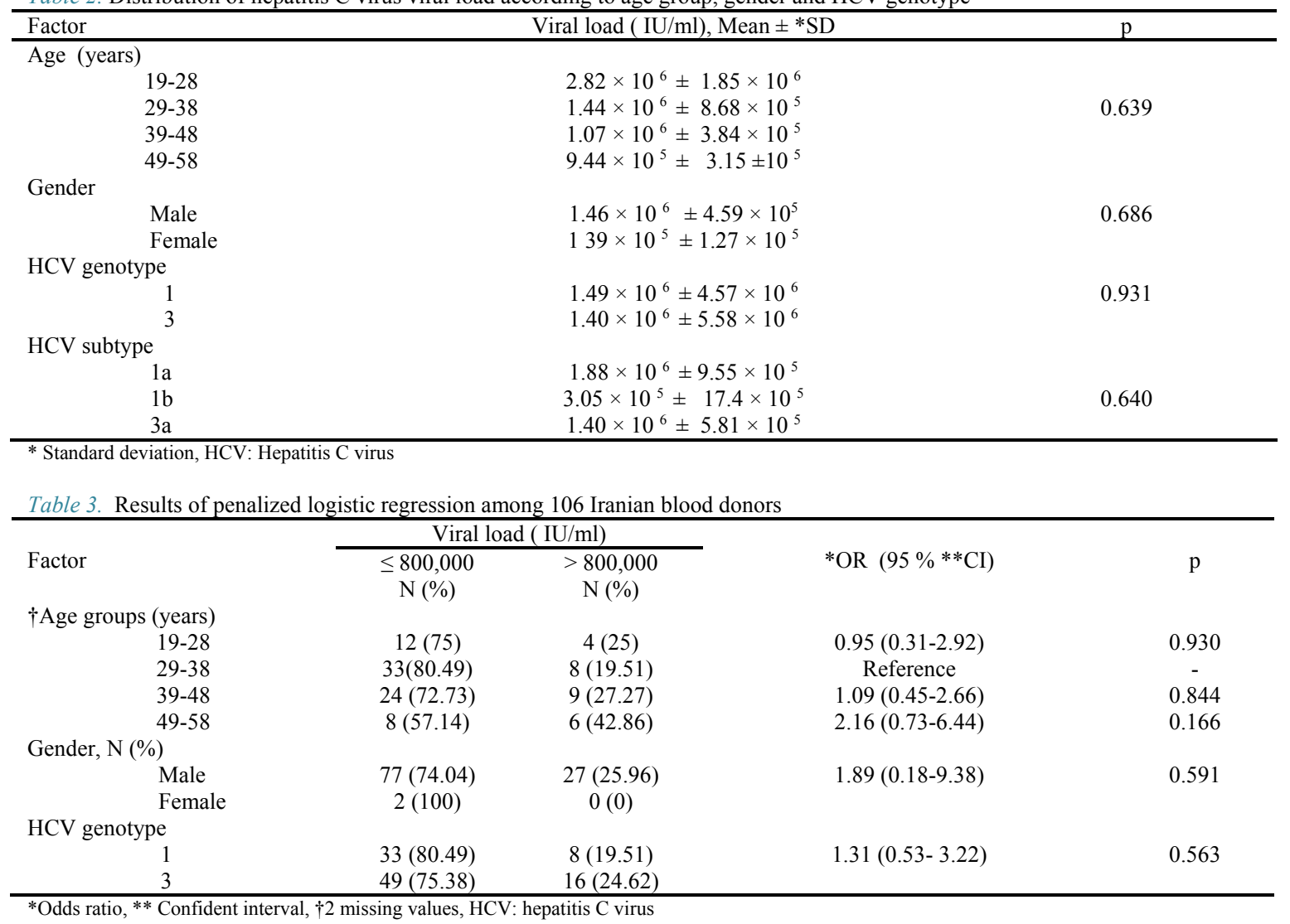


higher than in those with the other two genotypes, no significant association was found in this regard. This result is in line with the findings of a study reported from central regions of Iran that was conducted on 191 patients (16). Nishiya et al. revealed that the mean viral load of blood donors infected with HCV genotype 1a was higher than that of patients infected with HCV genotype 3a (29). Rong et al. reported that blood donors infected with HCV genotypes 1 and 6 are more likely to have higher viral loads than those infected with other genotypes (15). Generally, the association between higher mean viral load and genotype 1 was revealed in various populations in different geographical regions (10-14). Those studies confirmed higher efficiency of viral replication in genotype 1 compared to other genotypes.

In this study, based on the cut-off value of 800,000 $\mathrm{IU} / \mathrm{ml}, \mathrm{HCV}$ viral loads were categorized into low and high viral load. The frequency of subjects with high viral load was higher in genotype 3 than genotype 1, although the association was not significant (Table 3 ). The distribution of HCV genotype was comparable among subjects with viral load $\geq 800,000 \mathrm{IU} / \mathrm{ml}$ and total subjects. HCV genotype 3 was more frequent than genotype 1 in both groups $(66.67 \%$ vs. $33.33 \%$ in the former and $61.32 \%$ vs. $38.68 \%$ in the latter). This finding may clarify the role of high viral load in changes in the molecular epidemiology of HCV among Iranian blood donors and the replacement of previously dominant genotype 1a with the recently dominant genotype 3 (subtype $3 a$ ) over the years $(8,30)$.

An Iranian study conducted by Hajia et al. reported that subtype 1a was the most prevalent subtype among all study subjects, and this subtype had the highest rate among the subjects with viral loads higher than 800,000 $\mathrm{IU} / \mathrm{ml}$ (20). Studies in Pakistan showed that genotype 3 was the most frequent among total patients, and most patients with high viral loads $(>800,000 \mathrm{IU} / \mathrm{ml})$ were infected with genotype 3 , and the relation was significant (18, 19). In contrast, other studies in Pakistan reported genotype 3 was the most frequent genotype, but genotype 3 was not the one with the highest frequency among patients with high viral loads $(17,31)$. In a recent review by Zhang et al., a significant association was found between high viral load $\left(\geq 10^{6} \mathrm{IU} / \mathrm{ml}\right)$ and genotypes $1 \mathrm{~b}$ and $6 \mathrm{a}$ that are frequent genotypes in Korea (21). The positive association between HCV viral load and virus transmission rate has been reported in vertical and percutaneous exposure (32, 33).

Although with recent improvements of direct-acting agents (DAAs), the response rate of all genotypes are comparable, and treatment of patients infected with $\mathrm{HCV}$ genotype 3 remains a challenging issue. In addition, the response rate of patients with genotype 3 is lower than those with other genotypes (34).

Studies have indicated that hepatic steatosis is an independent factor for the severity and progression of liver diseases in chronic HCV patients (35). Steatosis is more likely to be associated with viral factors such as viral load than host factors in genotype 3 infected patients compared to other genotypes $(34,36)$. In the current study, the frequency of blood donors with viral load $>800,000 \mathrm{IU} / \mathrm{ml}$ was higher in blood donors infected with genotype 3 (26.15\%) compared to those with genotype 1 (24.39\%). Our finding is in agreement with the instruction of new DAAs available in Iran, which stated that cirrhosis patients infected with genotype 3 are difficult cases to treat and need more strengthened therapy and longer treatment duration (37). However, other studies discussed the role of HCV genotype 1a or other factors on a sustained virological response (SVR) to pegIFN- $\alpha / \mathrm{RVB}$ therapy among chronic HCV patients $(38,39)$.

However, a very recent report of a clinical trial in Iran showed an excellent response rate of newly available DAAs in Iranian cases infected with both genotypes 1 and 3 and demonstrated that genotype 3 is no longer difficult to treat (40).

In contrast to some part of Iran that HCV genotype $1 \mathrm{~b}$ was the dominant genotype (41), in the present study, the prevalence of HCV genotype $1 \mathrm{~b}$ was the lowest among Iranian blood donors $(9.43 \% \pm 6.05)$ and subjects with genotype $1 \mathrm{~b}$ were not included in statistical analysis, separately. In our study, the low sample size was the limitation. Although we used a penalized conditional logistic regression model in data analysis to control some statistical bias in the association between HCV genotype and HCV viral load, possibly due to limited sample size, no statistical significance was found in the regression model.

\section{Conclusion}

Although no significant association between HCV genotype and HCV viral load or HCV viral load groups was found, it seems that the frequency of blood donors with high viral loads is higher among blood donors infected with HCV genotype 3 (genotype 3a) than those infected with genotype 1 , which may have resulted in high circulation of genotype 3 a among Iranian blood donors. This finding is likely to give us insight into HCV transmission, particularly HCV genotype $3 \mathrm{a}$ as the most frequent genotype among Iranian blood donors, and may provide information on the treatment of HCV infected patients, especially those infected with genotype $3 \mathrm{a}$. Further studies are needed to verify the findings of this study.

\section{Acknowledgments}

The authors thank our colleagues in blood transfusion centers across the country for data and sample collection. Also, the authors thank all colleagues for their technical help at the Diagnostic Laboratory of Iranian Blood Transfusion Organization, Tehran, Iran.

\section{Approval of the study protocol}

The Ethics Committee of High Institute for Research and Education in Transfusion Medicine, Tehran, Iran, approved the study (code No: IR.TMI.REC.1394.1800).

\section{Conflict of Interests}

The authors declare that they have no competing interests. 


\section{References}

1. Lanini S, Easterbrook PJ, Zumla A, Ippolito G. Hepatitis C: global epidemiology and strategies for control. Clin Microbiol Infect. 2016;22(10):833-8

2. Organization WH. Hepatitis C Fact Sheet, update April 2017. Geneva: World Health Organization. www.who.int/mediacentre/factsheets/ fs204/en/.Accessed; 2017.

3. Organization WH. Global hepatitis report 2017: World Health Organization; 2017.

4. Mirminachi B, Mohammadi Z, Merat S, Neishabouri A, Sharifi AH, Alavian SH, et al. Update on the Prevalence of Hepatitis C Virus Infection Among Iranian General Population: A Systematic Review and Meta-Analysis. Hepat Mon. 2017;17(2)

5. Gu M, Rice CM. Structures of hepatitis $\mathrm{C}$ virus nonstructural proteins required for replicase assembly and function. Curr Opin Virol. 2013;3(2):129-36.

6. Simmonds P, Becher P, Bukh J, Gould EA, Meyers G, Monath T, et al. ICTV Virus Taxonomy Profile: Flaviviridae. J Gen Virol. 2017;98(1):2-3

7. Smith DB, Bukh J, Kuiken C, Muerhoff AS, Rice CM, Stapleton JT, et al. Expanded classification of hepatitis $\mathrm{C}$ virus into 7 genotypes and 67 subtypes: updated criteria and genotype assignment web resource. Hepatology. 2014;59(1):318-27.

8. Kermani FR, Amini-Kafiabad S, Hosseini KM, Maghsudlu M, Sharifi Z, Mansournia MA. Distribution of Hepatitis C Virus Genotypes and Related Risk Factors Among Iranian Blood Donors: A Penalized Logistic Regression. Jundishapur J Microbiol. 2018;11(12).

9. Pawlotsky JM, Negro F, Aghemo A, Berenguer M, Dalgard O, Dusheiko G, et al. EASL recommendations on treatment of hepatitis $\mathrm{C}$ 2018. J Hepatol. 2018 Aug;69(2):461-511

10. Burguete-García AI, Conde-González CJ, Jiménez-Méndez R, Juárez-Díaz Y, Meda-Monzón E, Torres-Poveda K, et al. Hepatitis C seroprevalence and correlation between viral load and viral genotype among primary care clients in Mexico. Salud Publica Mex. 2011;53:S7-S12.

11. Chakravarti A, Dogra G, Verma V, Srivastava AP. Distribution pattern of $\mathrm{HCV}$ genotypes \& its association with viral load. Indian J Med Res. 2011;133(3):326.

12. Doostan F, Jahanshahi MJ, Hassanzadeh F, Bazrafshani M. The Relationship between Hepatitis C Genotypes and Viral Load: a study on hepatitis C patients in Kerman, Iran using Real-time PCR. Journal of Kerman University of Medical Sciences. 2017;24(2):159-65.

13. Petruzziello A, Coppola N, Loquercio G, Marigliano S, Giordano M, Azzaro R, et al. Distribution pattern of hepatitis $\mathrm{C}$ virus genotypes and correlation with viral load and risk factors in chronic positive patients. Intervirology. 2014;57(6):311-8.

14. Soriano V, Mocroft A, Rockstroh J, Ledergerber B, Knysz B, Chaplinskas S, et al. Spontaneous viral clearance, viral load, and genotype distribution of hepatitis $\mathrm{C}$ virus $(\mathrm{HCV})$ in $\mathrm{HIV}$-infected patients with anti-HCV antibodies in Europe. J Infec. Dis. 2008;198(9):1337-44.

15. Rong X, Lu L, Wang J, Xiong H, Huang J, Chen J, et al. Correlation of viral loads with HCV genotypes: higher levels of virus were revealed among blood donors infected with 6 a strains. PLoS One. 2012;7(12):e52467.

16. Hadinedoushan H, Salmanroghani H, Amirbaigy MK, AkhondiMeybodi M. Hepatitis C virus genotypes and association with viral load in yazd, central province of iran. Hepat Mon. 2014;14(3).

17. Afridi SQ, Khan N, Akmal M, Ali S, Attaullah S, Bahadar S, et al. Distribution of HCV Genotypes and RNA Viral Load Along with Hemato-Biochemical Analysis of HCV Patients in Rahim Yar Khan, Okara and Toba Tek Singh Districts of Punjab, Pakistan. Hepat Mon. 2017; 17(7)

18. Afridi SQ, Ali MM, Awan F, Zahid MN, Afridi IQ, Afridi SQ, et al. Molecular epidemiology and viral load of $\mathrm{HCV}$ in different regions of Punjab, Pakistan. Virol J. 2014;11(1):24.

19. Ali A, Nisar $M$, Ahmad $H$, Saif $N$, Idrees $M$, Bajwa MA Determination of HCV genotypes and viral loads in chronic HCV infected patients of Hazara Pakistan. Virol J. 2011;8(1):466.

20. Hajia M, Amirzargar A, Khedmat H, Shahrokhi N, Farzanehkhah M, Ghorishi S, et al. Genotyping pattern among Iranian $\mathrm{HCV}$ positive patients. Iran J Public Health. 2010;39(2):39.

21. Zhang Y, Chen LM, He M. Hepatitis C Virus in mainland China with an emphasis on genotype and subtype distribution. Virol J.
2017;14(1):41.

22. Ranjbar Kermani F, Mousavi Hosseini K, Amini Kafi-Abad S, Mansournia M, Sharifi Z, Maghsudlu M. Hepatitis C (HCV) viremia rate and its correlation to demographic factors among $\mathrm{HCV}$ confirmed Iranian blood donors. Arch Iran Med. 2019;22(2): 76-79

23. Kermani FR, Kafi-Abad SA, Hosseini KM, Maghsoudlu M, Sharifi Z, Samiee S. Evaluation of the Performance Characteristics of an InHouse One Step TaqMan Real Time-Polymerase Chain Reaction Assay for Detection and Quantification of Hepatitis C Virus. Jundishapur J Microbiol. 2017;10(3)

24. Ghany MG, Strader DB, Thomas DL, Seeff LB. Diagnosis, management, and treatment of hepatitis $C$ : an update. Hepatology. 2009;49(4):1335-74.

25. JM P. Hepatitis C 101: What Does Viral Load Mean? https://hepatitisc.net/answers/what-does-viral-load-mean 2015

26. Greenland S, Mansournia MA. Penalization, bias reduction, and default priors in logistic and related categorical and survival regressions. Stat Med. 2015;34(23):3133-43.

27. Greenland S, Mansournia MA, Altman DG. Sparse data bias: a problem hiding in plain sight. BMJ. 2016;352:i1981.

28. Mansournia MA, Geroldinger A, Greenland S, Heinze G. Separation in Logistic Regression - Causes, Consequences, and Control. Am J Epidemiol. 2017;2016 Apr 27;352:i1981

29. Nishiya AS, de Almeida-Neto C, Ferreira SC, Alencar CS, DiLorenzo-Oliveira C, Levi JE, et al. HCV genotypes, characterization of mutations conferring drug resistance to protease inhibitors, and risk factors among blood donors in Sao Paulo, Brazil. PLoS One. 2014;9(1):e86413.

30. Mahmud S, Al-Kanaani Z, Chemaitelly H, Chaabna K, Kouyoumjian SP, Abu-Raddad LJ. Hepatitis C virus genotypes in the Middle East and North Africa: Distribution, diversity, and patterns. J Med Virol. 2018;90(1):131-41

31. Riaz S, Bashir MF, Haider S, Rahid N. Association of genotypes with viral load and biochemical markers in $\mathrm{HCV}$-infected Sindhi patients. Braz J Microbiol. 2016;47(4):980-6.

32. Yeung CY, Lee HC, Chan WT, Jiang CB, Chang SW, Chuang CK. Vertical transmission of hepatitis $\mathrm{C}$ virus: Current knowledge and perspectives. World J Hepatol. 2014;6(9):643.

33. Le Campion A, Larouche A, Fauteux-Daniel S, Soudeyns H Pathogenesis of hepatitis $\mathrm{C}$ during pregnancy and childhood. Viruses 2012;4(12):3531-50.

34. Sadler MD, Agarwal K. Treatment of genotype 3 chronic hepatitis C virus infection. Clinical Medicine Insights: Therapeutics. 2017:9:1179559X17694330

35. Roingeard $\mathrm{P}$. Hepatitis $\mathrm{C}$ virus diversity and hepatic steatosis J. Viral Hepat. 2013;20(2):77-84.

36. Chan A, Patel K, Naggie S. Genotype 3 Infection: The last stand of hepatitis C virus. Drugs. 2017;77(2):131-44.

37. Alavian SM, Sharafi H, Mirshamsi M, Vazirizadeh A, Omranipour R, Fakhri A, et al. Update on Recommendations for the Clinical Management of Hepatitis C in Iran 2017. Hepat Mon. 2017 November; 17(11):e63956.

38. Fateh A, Aghasadeghi MR, Keyvani H, Mollaie HR, Yari S, Hadizade Tasbiti AR, et al. High resolution melting curve assay for detecting rs12979860 IL28B polymorphisms involved in response of Iranian patients to chronic hepatitis $\mathrm{C}$ treatment. Asian Pac J Cancer Prev. 2015; 16:1873-1880.

39. Sadeghi F, Bokharaei-Salim F, Salehi-Vaziri M, Monavari SH, Alavian SM, Salimi S, et al. Associations between human TRIM22 gene expression and the response to combination therapy with PegIFN $\alpha-2 \mathrm{a}$ and ribavirin in Iranian patients with chronic hepatitis C. J Med Virol. 2014;86(9):1499-506.

40. Merat S, Sharifi AH, Haj-Sheykholeslami A, Poustchi H, Fattahi B, Nateghi-Baygi A, et al. The efficacy of 12 weeks of sofosbuvir, daclatasvir, and ribavirin in treating hepatitis $\mathrm{C}$ patients with cirrhosis, genotypes 1 and 3. Hepat Mon. 2017;17(1).

41. Bokharaei-Salim F, Keyvani H, Monavari SH, Alavian SM, Fakhim $\mathrm{S}$, Nasseri S. Distribution of hepatitis $\mathrm{C}$ virus genotypes among azerbaijani patients in capital city of iran-tehran. Hepat Mon. 2013;13(9). 